\title{
Efficacy of Benzocaine, Eugenol, and Menthol as Anesthetics for Freshwater Angelfish
}

\author{
Rafael de Souza Romaneli, André Zuffo Boaratti, Andressa Tellechea Rodrigues, \\ Daniel Monge de Almeida Queiroz, Kifayat Ullah Khan, Thiago Matias Torres Nascimento, and \\ João Batista Kochenborger Fernandes \\ Aquaculture Center, São Paulo State University, Via de Acesso Paulo Donato Castellane s/n, 14884-900 Jaboticabal, \\ São Paulo, Brazil
}

Cleber Fernando Menegasso Mansano*

Campus Fernandópolis, Brazil University, Estrada Projetada F-1, s/n Fazenda Santa Rita, 15600-000 Fernandópolis, São Paulo, Brazil

\begin{abstract}
For the production and commercialization of ornamental fish species, it is indispensable to collect biometric data that facilitate the selection of animals for trade and genetic improvement of the stock. However, during the handling process, fish receive more stress if proper anesthetics are not used. Thus, application of appropriate anesthetics is an important tool for minimizing stress in animals. The objective of this study was to determine the effective concentrations of benzocaine, eugenol, and menthol for achieving anesthesia in Freshwater Angelfish Pterophyllum scalare and to develop induction and recovery response curves for different concentrations of these anesthetics. In total, 75 fish were exposed to five concentrations of the three anesthetics in a completely randomized design: benzocaine at 60,85 , 110,135 , and $160 \mathrm{mg} / \mathrm{L}$; eugenol at 40, 80, 120, 160, and $200 \mathrm{mg} / \mathrm{L}$; and menthol at 50, 75, 150, 200, and $250 \mathrm{mg} / \mathrm{L}$. Each concentration ( $5 \mathrm{fish} /$ concentration) consisted of five replicates, with each replicate represented by a single fish. The results indicated that the tested substances met the criteria of anesthetic efficiency. The effective concentrations of benzocaine, eugenol, and menthol for the anesthesia of Freshwater Angelfish were identified as 89.25, 90.6, and 92.1 $\mathrm{mg} / \mathrm{L}$, respectively.
\end{abstract}

For the production and commercialization of ornamental fish species, it is important to conduct studies regarding biometrics that facilitate the selection of species for trade and genetic improvement of stocks as well as the transport of animals to market for sale. However, during biometric studies, animals undergo stress, which can be harmful for their well-being. Thus, the use of proper anesthetics in effective concentrations is an important tool for the reduction of stress (Ross and Ross 1999). The careful use of anesthetics can increase safety for both the fish and the handler during minor procedures and allows fish to be handled out of the water with decreased stress (Harms and Bakal 1995), thus directly reducing the secondary stress responses and preventing delayed mortality (Cooke et al. 2004).

Stimulation of the hypothalamic-pituitary-interrenal (HPI) axis triggers cortisol release in fish during handling practices, which produces secondary stress responses (Bressler and Ron 2004). The intensity and duration of the stress response depend on the duration of exposure, the anesthetic quality and concentration, and the species (Thomas and Robertson 1991; Gomes et al. 2001; Bressler

*Corresponding author: clebermansano@yahoo.com.br

Received October 24, 2017; accepted May 20, 2018 
and Ron 2004). The use of effective anesthetic concentrations blocks the stimulation or activation of the HPI axis, stops the cortisol release, and minimizes the movement and physiological changes in response to nociception (Harms and Bakal 1995; Ross 2001; Myszkowski et al. 2003). Consequently, the chance of integument damage and osmoregulatory instability decreases (Kumlu and Yanar 1999; Ross 2001), and the metabolic process becomes slow, resulting in reduced oxygen demand and low waste production (Cooke et al. 2004; Crosby et al. 2006).

The characteristics of a suitable anesthetic should be to induce the animal to anesthesia up to a maximum of $3 \mathrm{~min}$, allow recovery in up to $5 \mathrm{~min}$, and promote low residual concentration in the animal after $1 \mathrm{~h}$ of depuration (Marking and Meyer 1985). Moreover, it should not cause any toxicity to the fish; should demonstrate a good range of safety for those who handle it; and should have a low cost. A wide variety of synthetic anesthetic compounds is available for fish (Marking and Meyer 1985). One of them is benzocaine, which is widely used for the anesthesia of aquatic animals because of its easy accessibility and applicability (Gomes et al. 2001; Inoue et al. 2002; Façanha and Gomes 2005). In addition, it presents good efficiency as an anesthetic, has a safe range of application, and does not cause any toxicity when used in appropriate concentrations (Burka et al. 1997; Roubach and Gomes 2001). Benzocaine is considered to be environmentally friendly and is thus used frequently without causing any reproductive or growth changes (Roubach and Gomes 2001).

According to Gomes et al. (2001), benzocaine is widely used for anesthetic procedures in fish and has been tested for efficacy with Nile Tilapia Oreochromis niloticus (Okamura et al. 2010), Goldfish Carassius auratus (Bittencourt et al. 2012), and Common Carp Cyprinus carpio (Bittencourt et al. 2013). However, some natural substances have been used as anesthetics due to the demand of the ornamental fish industry for nonsynthetic substances. In this respect, eugenol and menthol have been studied while maintaining appropriate animal welfare and low cost (Roubach et al. 2005).

Eugenol is the active ingredient derived from clove oil. Clove oil consists of $70-95 \%$ eugenol (Mazzafera 2003). It is also widely used as an anesthetic and is available naturally. Eugenol is also rapidly eliminated from the bloodstream (Woody et al. 2002). Moreover, it has a low cost, has good efficacy, and is easily available. It is considered safe for the animal, the environment, and the people who manipulate it and has been used for a long time by the food, dental, and cosmetic industries (Keene et al. 1998; Inoue et al. 2003; Iversen et al. 2003; Barbosa et al. 2007).

Another anesthetic agent that can be used for fish anesthesia is menthol, an essential oil extracted from mint
Mentha arvensis (Matos 2000; Patel et al. 2007). It has anesthetic, antispasmodic, anti-inflammatory, anti-ulcer, and antiviral properties (Lorenzo et al. 2002). Menthol is considered a safe compound for animal life and is thus used in various pharmaceuticals, cosmetics, and food industries (Lorenzo et al. 2002; Gelal 2008). It can be easily and cheaply purchased at pharmacies (Façanha and Gomes 2005; Roubach et al. 2005). This compound has been shown to have efficacy in anesthesia of the Tambaquí Colossoma macropomum (Façanha and Gomes 2005), Pacu Piaractus mesopotamicus (Gonçalves et al. 2008), and Nile Tilapia (Teixeira et al. 2011).

The Freshwater Angelfish Pterophyllum scalare is endemic to the Amazon region and is distributed as an ornamental fish species in Brazil, Peru, Colombia, and Guianas (Cacho et al. 1999; Soriano and Ocampo 2002) as well as in several other countries of the world, including the USA, Philippines, Singapore, Suriname, Israel, and Mexico (FAO 2017). It is distinctive among other native ornamental species due to its beauty, peaceful behavior, easy and rapid adaptation to different production systems, easy reproduction in captivity, and good market value (Chapman et al. 1997; Fujimoto et al. 2006; Ribeiro et al. 2008). Although some studies have been carried out on the efficacy of benzocaine, eugenol, and menthol in this ornamental fish species, response curves have not been developed. Therefore, the objective of this study was to determine the effective concentrations of benzocaine, eugenol, and menthol for Freshwater Angelfish and to develop induction and recovery response curves for different anesthetic concentrations.

\section{METHODS}

The experiment was conducted at the Ornamental Fish Laboratory, Aquaculture Center, São Paulo State University, São Paulo, Brazil. The fish used in the present trials were reproduced at the same laboratory. All procedures followed in the trial were according to the ethical guidelines described by the Brazilian College of Animal Experimentation regarding the use of animals for experimental purposes and were approved by the Ethics Committee on Animal Use at São Paulo State University (Protocol Number 012036/17). A total of 75 fish (25 fish/anesthetic; average body weight $=16.45 \pm 1.75 \mathrm{~g}$ [mean $\pm \mathrm{SD}]$ ), regardless of sex (i.e., both sexes), was used in the present study. Before each test, the required number of fish ( 25 fish/trial) was distributed to a single, large glass aquarium (capacity $=150 \mathrm{~L} ; \quad$ length $\times$ width $\times$ height $=1.23 \times 0.30 \times$ $0.41 \mathrm{~m}[48 \times 12 \times 16 \mathrm{in}])$ and acclimated for 1 week in semi-static conditions. After the acclimation period, five aquaria $\quad$ (capacity $=40 \mathrm{~L}$; length $\times$ width $\times$ height $=$ $0.51 \times 0.25 \times 0.30 \mathrm{~m}[20 \times 10 \times 12$ in $])$ were assigned to each concentration of an anesthetic for the assessment of 
induction. During each test, fish were transferred one by one via small hand nets to their respective aquaria (1 fish/ aquarium), provided with a respective concentration of an anesthetic. The anesthetized fish were then transferred individually to another five anesthetic-free aquaria assigned to recovery times. This procedure was performed for all concentrations of each anesthetic, totaling five concentrations per anesthetic and five replicates per concentration. The three trials were conducted consecutively but separately in order to avoid cross-contamination between the trials. Each trial was blinded: the two observers had no idea which treatment they were evaluating.

The animals were exposed to five concentrations of each of the three anesthetics in a completely randomized design: benzocaine (4-aminobenzoic acid ethyl ester; Sigma-Aldrich, Brazil; 60, 85, 110, 135, and $160 \mathrm{mg} / \mathrm{L}$ ), eugenol (eugenol United States Pharmacopeia, 99-100.5\%; Biodynamics Chemicals and Pharmaceuticals Ltd., Brazil; 40, 80, 120, 160, and $200 \mathrm{mg} / \mathrm{L}$ ), and menthol (2-isopropyl-5-methylcyclohexanol M2772; Sigma-Aldrich; 50, 75, 150,200 , and $250 \mathrm{mg} / \mathrm{L}$ ).

The anesthetic concentrations used in the present trials were selected according to the concentrations determined by Costa (2011) and Mello et al. (2012) for Nile Tilapia, where minimum and maximum concentrations (40$160 \mathrm{mg} / \mathrm{L}$ ) were studied. In the case of menthol, it was necessary to increase the concentration up to a maximum level of $250 \mathrm{mg} / \mathrm{L}$ because in a pilot study (described below), fish demonstrated a low response (slow induction) to lower menthol concentrations.

The anesthetics are commonly insoluble in water (Mitjana et al. 2014). Therefore, to ensure proper mixing, a stock solution $(100 \mathrm{mg} / \mathrm{mL})$ was prepared just before each trial by dissolving an anesthetic concentration in absolute ethanol (1:9 volume/volume) as described by Mitjana et al. (2014). The anesthetic concentrations were directly administered into aquaria through 5-mL syringes (INJEX Indústrias Cirúrgicas Ltd., Brazil). No toxic or anesthetic effects have been observed with the use of ethanol at the aforementioned concentration in juvenile Freshwater Angelfish (Woody et al. 2002). The above-mentioned concentration of the solvent has also shown no interactions with any of the three anesthetics in terms of anesthesia induction and recovery (Woody et al. 2002; Mitjana et al. 2014).

A pilot experiment was conducted with the same experimental design (anesthetics, treatments, replicates, aquaria, and size of fish) as mentioned above. During the pilot study, characteristics to gauge the induction and recovery were evaluated on the basis of criteria described in Table 1, and a maximum time of $15 \mathrm{~min}$ was specified for each anesthetized animal (Woody et al. 2002). Two persons thoroughly observed the behavioral changes in the juvenile Freshwater Angelfish, such as opercular movements, equilibrium, and absence of tactile movements in response to the three anesthetics. Anesthetic stages were consistent with those described by Woody et al. (2002; Table 1). No significant difference was observed between the times recorded by both viewers $(P<0.05)$, indicating that they observed the behavior consistently. After induction, recovery times were evaluated for $5 \mathrm{~min}$, as well as any mortality within seven consecutive days after anesthesia induction.

Determination of the optimal values for induction and recovery times per anesthetic concentration was performed using the linear response plateau (LRP) model. The values were also subjected to the ANOVA procedure in SAS (SAS Institute 2014). Tukey's test was used $(P<0.05)$ to compare the averages. Analyses were performed using SAS software.

\section{RESULTS}

During the trials, no mortality or physiological alterations were observed. The water quality parameters, such as temperature (average $=27.05 \pm 0.64^{\circ} \mathrm{C}[$ mean $\pm \mathrm{SD}]$ ), dissolved oxygen $(6.77 \pm 0.21 \mathrm{mg} / \mathrm{L})$, and $\mathrm{pH}(6.91 \pm 0.42)$ were measured daily and found within the range suggested for Freshwater Angelfish by Pérez et al. (2003) and Ribeiro et al. (2008). The induction concentrations of benzocaine, eugenol, and menthol determined by using the broken-line model for the anesthesia of Freshwater Angelfish are shown in Table 2.

\section{Benzocaine}

Benzocaine concentrations of 110,135 , and $160 \mathrm{mg} / \mathrm{L}$ resulted in significantly rapid induction times less than 3 min. Induction times decreased with increasing anesthetic concentrations (Figure 1). However, no change in recovery time was observed between the treatments; average time for recovery was $2.5 \pm 0.71$ min (mean $\pm \mathrm{SD}$ ).

TABLE 1. Behavioral stages of anesthesia induction and recovery in fish as described by Woody et al. (2002).

\begin{tabular}{ll}
\hline Stage & \multicolumn{1}{c}{ Behavior characteristics } \\
\hline 1 & Visibly slow or erratic opercular movement \\
2 & $\begin{array}{c}\text { Partial loss of balance and difficulty in } \\
\text { maintaining normal swimming position when } \\
\text { stopped }\end{array}$ \\
3 & $\begin{array}{l}\text { Total loss of balance and inability to regain } \\
\text { the vertical position of swimming ("belly }\end{array}$ \\
4 & up") \\
Absence of response to any stimulus \\
Recovered \\
Recovery of normal swimming position and \\
ability to swim
\end{tabular}


TABLE 2. Induction concentrations of benzocaine, eugenol, and menthol determined for Freshwater Angelfish by using the broken-line model.

\begin{tabular}{llcrr}
\hline Anesthetic & \multicolumn{1}{c}{ Equation } & $\begin{array}{c}\text { Induction concentration } \\
(\mathrm{mg} / \mathrm{L})\end{array}$ & $R^{2}$ & $P$-value \\
\hline Benzocaine & $y=102.7-16.296(89.2546-x)$ & 89.2 & 0.96 & 0.0001 \\
Eugenol & $y=79.0-9.605(90.5986-x)$ & 90.6 & 0.86 & 0.0001 \\
Menthol & $y=116.0-18.624(92.0962-x)$ & 92.1 & 0.94 & 0.0001 \\
\hline
\end{tabular}

The induction time values were entered into the LRP model to obtain the effective concentration of benzocaine for induction, as indicated by the breaking point of the line (Table 2). The effective concentration of benzocaine for anesthesia induction in Freshwater Angelfish was identified as $89.25 \mathrm{mg} / \mathrm{L}$, with a time of $102.7 \mathrm{~s}$.

\section{Eugenol}

Concentrations of 120,160 , and $200 \mathrm{mg} / \mathrm{L}$ resulted in induction times less than $3 \mathrm{~min}$, and induction times decreased with increasing anesthetic concentration (Figure 2; Table 2). However, for the recovery time, no change was observed between the treatments; average recovery time across treatments was $3.5 \pm 0.71 \mathrm{~min}$. The effective concentration of eugenol for anesthesia induction in Freshwater Angelfish was $90.6 \mathrm{mg} / \mathrm{L}$, with a time of $79 \mathrm{~s}$, which was the shortest time observed among the three anesthetics tested.

\section{Menthol}

Induction times decreased with increasing menthol concentration; $150-250-\mathrm{mg} / \mathrm{L}$ concentrations resulted in induction times less than $3 \mathrm{~min}$ (Figure 3). For the recovery time, changes were observed between the treatments, with an average of $4 \pm 1.41 \mathrm{~min}$ required for full recovery of the fish. According to the LRP model (Table 2), the effective concentration of menthol for anesthesia induction in Freshwater Angelfish was $92.1 \mathrm{mg} / \mathrm{L}$, with a time of $116 \mathrm{~s}$.

\section{DISCUSSION}

The present study indicates that benzocaine is an effective anesthetic substance for Freshwater Angelfish anesthesia. Values obtained in this study were close to those reported by Gimbo et al. (2008) for the Twospot Astyanax Astyanax bimaculatus $(100 \mathrm{mg} / \mathrm{L})$ and by Bittencourt et al. (2013) for the Common Carp (87-100 mg/L). According to Marking and Meyer (1985), for an anesthetic to be efficient, it should present an induction time less than $3 \mathrm{~min}$ and a recovery time within $5 \mathrm{~min}$ - values that were obtained for all anesthetics tested in this study.

Benzocaine did not promote any toxic effect in Freshwater Angelfish even at the higher dosage of $160 \mathrm{mg} / \mathrm{L}$, since the dosages chosen were in accordance with specifications for other freshwater fish (Roubach and Gomes 2001). After the procedures, the fish were observed for $7 \mathrm{~d}$, and no mortality was seen. However, Gimbo et al. (2008) observed large number of Twospot Astyanax mortalities during a 7-d period after exposure to an anesthetic dose of $125 \mathrm{mg} / \mathrm{L}$. Chellapan et al. (2013) reported that exposure of Freshwater Angelfish to high concentrations of benzocaine caused oxygen reduction that later negatively affected the respiratory system.

The present study demonstrated that eugenol had good anesthetic effects, with an effective dosage of $90.6 \mathrm{mg} / \mathrm{L}$. However, the $40-\mathrm{mg} / \mathrm{L}$ concentration of eugenol presented a longer induction time $(687 \mathrm{~s})$, which did not fit the

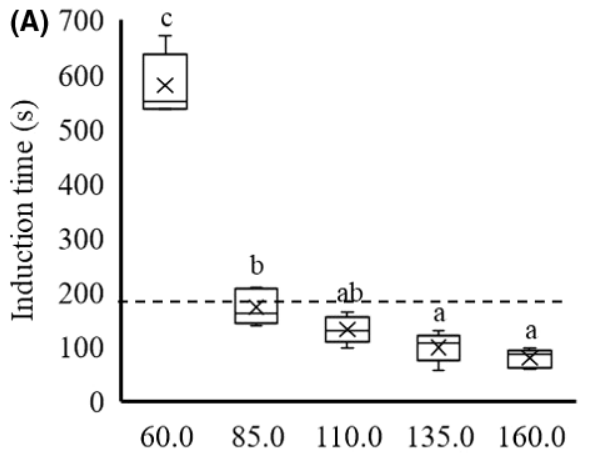

Benzocaine concentration (mg L-1)

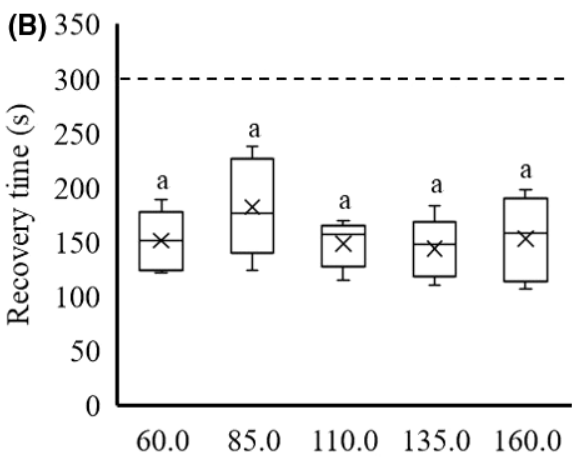

Benzocaine concentration (mg L-1)

FIGURE 1. (A) Induction times and (B) recovery times for Freshwater Angelfish anesthetized with five benzocaine concentrations. The upper and lower lines of each plot represent the maximum and minimum times observed; the $\times$ symbol represents the median; and the inner box represents the 25 th and 75 th percentiles. The dashed line indicates the optimal induction time $(<180 \mathrm{~s})$ and optimal recovery time (within $300 \mathrm{~s})$ suggested by Marking and Meyer (1985). Different letters represent significant differences (Tukey's test: $P<0.05$ ). 

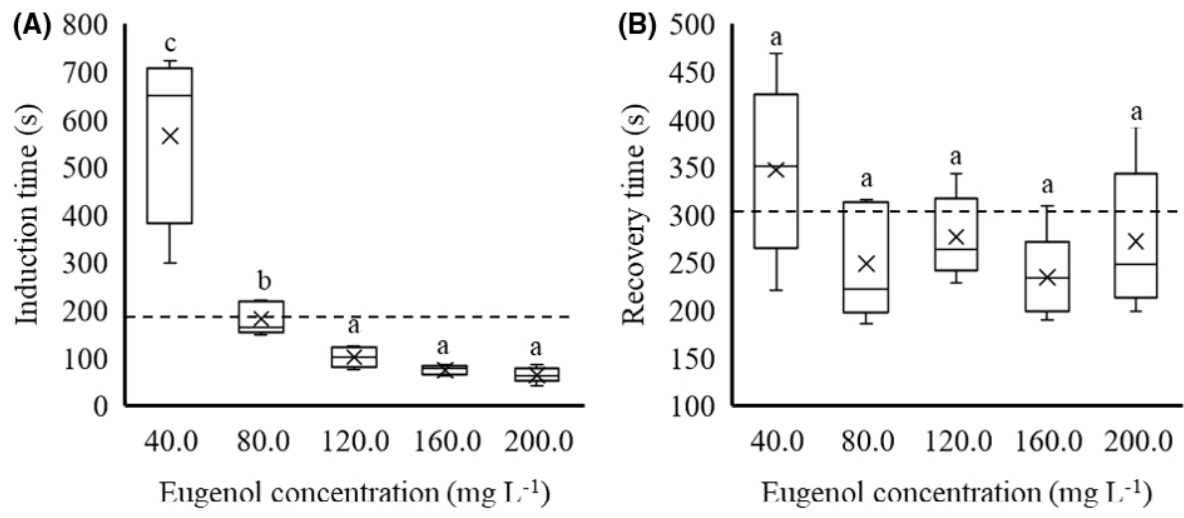

FIGURE 2. (A) Induction times and (B) recovery times for Freshwater Angelfish anesthetized with five eugenol concentrations. The upper and lower lines of each plot represent the maximum and minimum times observed; the $\times$ symbol represents the median; and the inner box represents the 25 th and 75th percentiles. The dashed line indicates the optimal induction time $(<180 \mathrm{~s})$ and optimal recovery time (within $300 \mathrm{~s})$ suggested by Marking and Meyer (1985). Different letters represent significant differences (Tukey's test: $P<0.05$ ).

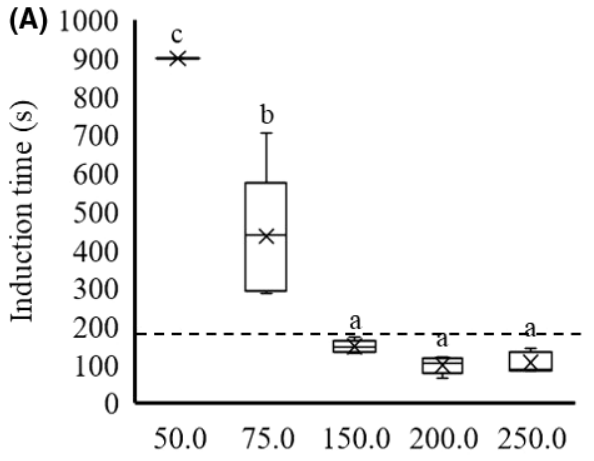

Menthol concentration ( $\left.\mathrm{mg} \mathrm{L}^{-1}\right)$

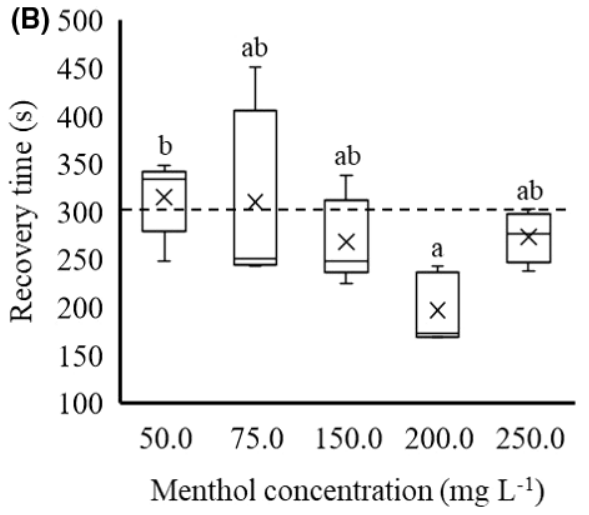

FIGURE 3. (A) Induction times and (B) recovery times for Freshwater Angelfish anesthetized with five menthol concentrations. The upper and lower lines of each plot represent the maximum and minimum times observed; the $\times$ symbol represents the median; and the inner box represents the 25 th and 75th percentiles. The dashed line indicates the optimal induction time $(<180 \mathrm{~s})$ and optimal recovery time (within $300 \mathrm{~s})$ suggested by Marking and Meyer (1985). Different letters represent significant differences (Tukey's test: $P<0.05$ ).

specifications described by Marking and Meyer (1985). According to Millan-Ocampo et al. (2012), Chellapan et al. (2013), Mitjana et al. (2014), and Tarkhani et al. (2017), eugenol is an efficient anesthetic for Freshwater Angelfish. Mitjana et al. (2014) concluded that eugenol at $100 \mathrm{mg} / \mathrm{L}$ is appropriate for Freshwater Angelfish (average body weight $=2.46 \pm 0.60 \mathrm{~g}$ [mean $\pm \mathrm{SD}]$ ), which is similar to the results of this study. Tarkhani et al. (2017) recommended a much lower eugenol concentration $(5.5 \mathrm{mg} / \mathrm{L})$ for Freshwater Angelfish, but their study fish were smaller (1-, 5-, and 10-g weight categories) than those used here. Millan-Ocampo et al. (2012) and Chellapan et al. (2013) reported intermediate effective eugenol concentrations ( 40 and $45 \mathrm{mg} / \mathrm{L}$ ) for induction of Freshwater Angelfish that were of similar size to those used by Tarkhani et al. (2017).

The variation in the recommendations for eugenol may be due to the difference in fish species, fish size, anesthetic concentration, experimental design, or statistical analysis. Eugenol concentrations determined for the Nile Tilapia (Vidal et al. 2008), Pacu (Gonçalves et al. 2008), and Smallscale Fat Snook Centropomus parallelus (Souza et al. 2012) were variable, and the concentrations obtained were lower than those determined for Freshwater Angelfish (50, 50, and $37.5 \mathrm{mg} / \mathrm{L}$, respectively). Bittencourt et al. (2012) observed an appropriate eugenol concentration of $75 \mathrm{mg} / \mathrm{L}$ for Goldfish, which is close to that determined in this study $(90.6 \mathrm{mg} / \mathrm{L})$, while Ramos et al. (2015) recommended higher dosages of $120 \mathrm{mg} / \mathrm{L}$ for the Zebra Pleco Hypancistrus zebra and $140 \mathrm{mg} / \mathrm{L}$ for Ancistrus ranunculus and for the Gold Nugget Pleco Baryancistrus xanthellus.

Menthol also demonstrated efficacy in relation to the criteria established by Marking and Meyer (1985) regarding the effectiveness of an anesthetic during fish handling. The optimal dose of menthol in this study was identified as $92.1 \mathrm{mg} / \mathrm{L}$. According to Façanha and Gomes (2005), 
menthol was an effective anesthetic agent for Tambaquí, and the optimal concentration of menthol for induction during biometric data collection was $100 \mathrm{mg} / \mathrm{L}$. Moreover, those authors reported that induction after exposure of Tambaquí to an adequate concentration of menthol may last up to 30 min without causing any mortality or physiological disturbances. However, in the present study, menthol concentrations between 50 and $75 \mathrm{mg} / \mathrm{L}$ yielded the highest induction times, although fish exposed to $50 \mathrm{mg} / \mathrm{L}$ did not reach stage 4 (Table 1). Thus, both doses are inefficient for anesthesia of this species, and care should be taken before using menthol, since the use of inadequate concentrations could lead to future problems.

According to Roubach et al. (2001), since the surface area for absorption of an anesthetic agent is higher in smaller fish, they absorb more anesthetic than larger fish; consequently, the induction time in smaller individuals is faster, and recovery is slower. The anesthetic responses evident in this study may be related the larger body sizes of fish used compared to previous studies. However, in evaluating menthol as an anesthetic, Façanha and Gomes (2005) did not observe any difference in induction or recovery times between juvenile and adult Tambaquí.

Souza et al. (2012) tested the same three anestheticsbenzocaine, eugenol, and menthol-for juvenile Smallscale Fat Snook to determine their efficiency and economic value and to improve the knowledge (induction times, full recovery times, and physiological changes) regarding each product. Those authors concluded that eugenol had the best cost-benefit ratio for fish anesthesia. However, price fluctuations in different regions or countries of the world may occur, since eugenol and menthol are most easily found at a lower cost in pharmacies.

In conclusion, benzocaine, eugenol, and menthol are effective anesthetics for use with the Freshwater Angelfish. The effective concentrations for anesthesia of Freshwater Angelfish were $89.25-\mathrm{mg} / \mathrm{L}$ benzocaine, $90.6-\mathrm{mg} / \mathrm{L}$ eugenol, and $92.1-\mathrm{mg} / \mathrm{L}$ menthol. The exposure of Freshwater Angelfish to effective concentrations of the anesthetics has demonstrated efficient anesthesia induction in $3 \mathrm{~min}$ and a recovery time of $5 \mathrm{~min}$ without causing any mortality or pathological signs.

\section{ACKNOWLEDGMENTS}

We thank the São Paulo State Research Foundation for provision of the technical training grant (Process 2016/ 11940-2) and financial support (2013/25761-4), and we thank the Ornamental Fish Laboratory at the Aquaculture Center, São Paulo State University, for providing necessary facilities during the trials. There is no conflict of interest declared in this article.

\section{ORCID}

Cleber Fernando Menegasso Mansano (D) http://orcid.org/ 0000-0001-8415-1145

\section{REFERENCES}

Barbosa, L. G., G. Moraes, and L. A. K. A. Inoue. 2007. Respostas metabólicas do Matrinxã (Brycon amazonicus) submetido a banhos anestésicos de eugenol. Acta Scientiarum, Biological Sciences, Maringá 29:255-260.

Bittencourt, F., B. E. D. Souza, D. H. Neu, R. R. Rarato, W. R. Boscolo, and A. Feiden. 2013. Eugenol e benzocaína como anestésicos para juvenis de Cyprinus carpio Linnaeus, 1758 (Carpa Comum). Revista Brasileira de Ciências Agrárias 8:163-167.

Bittencourt, F., B. E. Souza, R. R. Rorato, A. Feiden, and D. H. Neu. 2012. Benzocaína e eugenol como anestésicos para o quinguio (Carassius auratus). Arquivo Brasileiro de Medicina Veterinária e Zootecnia 64:1597-1602.

Bressler, K., and B. Ron. 2004. Effect of anesthetics on stress and the innate immune system of Gilthead Bream (Sparus aurata). Israeli Journal of Aquaculture 56:5-13.

Burka, J. F., K. L. Hammell, T. E. Horsberg, G. R. Johnson, D. J. Rainnie, and D. J. Speare. 1997. Drugs in salmonid aquaculture. Journal of Veterinary Pharmacology and Therapeutics, Oxford 20:333-349.

Cacho, M. S. R. F., M. E. Yamamo, and S. Chellappa. 1999. Comportamento reprodutivo do acará bandeira, Pterophyllum scalare. Revista Brasileira de Zoologia, Curitiba 16:653-664.

Chapman, F. A., S. A. Fitz-Coy, E. M. Thunberg, and C. M. Adams. 1997. United States of America trade in ornamental fish. Journal of the World Aquaculture Society 28:1-10.

Chellapan, A., C. B. T. Rajagopalsamy, and G. I. Jasmine. 2013. Effect of clove oil and benzocaine on the respiratory metabolism of Angel Fish, Pterophyllum scalare. Indian Journal of Science and Technology 6:4853-4861

Cooke, S. J., C. D. Suski, K. G. Ostrand, B. L. Tufts, and D. H. Wahl. 2004. Behavioral and physiological assessment of low concentrations of clove oil anesthetic for handling and transporting Largemouth Bass (Micropterus salmoides). Aquaculture 239:509-529.

Costa, L. S. 2011. Avaliação de óleo de cravo e benzocaína como anestésicos para juvenis de Tilápia Nilótica. Universidade Federal do Lavras, Lavras, Brazil.

Crosby, T. C., J. E. Hill, C. A. Watson, and R. P. E. Yanong. 2006. Effects of tricaine methanesulfonate, Hypno, metomidate, quinaldine, and salt on plasma cortisol levels following acute stress in Threespot Gourami Trichogaster trichopterus. Journal of Aquatic Animal Health 18:58-63.

Façanha, M. F., and L. C. Gomes. 2005. A eficácia do mentol como anestésico para Tambaqui (Colossoma macropomum, Characiformes: Characidae). Acta Amazônica, Manaus 35:71-75.

FAO (Food and Agriculture Organization of the United Nations). 2017. Aquaculture regional reviews. FAO Fisheries and Aquaculture Department, Rome.

Fujimoto, R. Y., L. Vendruscolo, S. H. C. Schalch, and F. R. D. Moraes. 2006. Avaliação de três diferentes métodos para o controle de monogenéticos e Capillaria sp. (Nematoda: Capillariidae), parasitos de acará-bandeira (Pterophyllum scalare Liechtenstein, 1823). Boletim do Instituto de Pesca, São Paulo 32:183-190.

Gelal, A. 2008. Influence of menthol on first pass elimination. Boletín Latinoamericano y del Caribe de Plantas Medicinales y Aromáticas, Santiago 7:119-124.

Gimbo, R. Y., M. V. Saita, A. F. N. Gonçalves, and L. S. Takahashi. 2008. Diferentes concentrações de benzocaína na indução anestésica 
do Lambari-do-Rabo-Amarelo (Astyanax altiparanae). Revista Brasileira de Saúde e Produção Animal 9:350-357.

Gomes, L. C., A. C. Chippari-Gomes, N. P. Lopes, R. Roubach, and C. A. R. M. Arauji-Lima. 2001. Efficacy of benzocaine as an anesthetic in juvenile Tambaqui Colossoma macropomum. Journal of the World Aquaculture Society 32:426-431.

Gonçalves, A. F. N., E. C. C. Santos, J. B. K. Fernandes, and L. S. Takahashi. 2008. Mentol e eugenol como substitutos da benzocaína na indução anestésica de juvenis de Pacu. Acta Scientiarum Animal Sciences, Maringá 30:339-344.

Harms, C. A., and R. S. Bakal. 1995. Techniques in fish anesthesia. Small Exotic Animal Medicine 3:19-25.

Inoue, L. A. K. A., C. dos Santos Neto, and G. Moraes. 2003. Clove oil as anesthetic for juveniles of Matrinxã Brycon cephalus (Gunther, 1869). Ciência Rural, Santa Maria 33:943-947.

Inoue, L. A. K. A., N. C. Santos, and G. Moraes. 2002. Benzocaína como anestésico para juvenis de Matrinxã (Brycon cephalus). Boletim Tecnico da Petrobras CEPTA (Centro Nacional de Pesquisa e Conservação de Peixes Continentais) 15:23-30.

Iversen, M., B. Finstad, R. S. Mckinley, and R. A. Eliassen. 2003. The efficacy of metomidate, clove oil, Aqui-S and Benzoak as anesthetics in Atlantic Salmon (Salmo solar L.) smolts, and their potential stressreducing capacity. Aquaculture 221:549-566.

Keene, J. L., D. L. G. Noakes, R. D. Moccia, and C. G. Soto. 1998. The efficacy of clove oil as an anesthetic for Rainbow Trout Oncorhynchus mykiss (Walbaum). Aquaculture Research 29:89-101.

Kumlu, M., and M. Yanar. 1999. Effects of the anesthetic quinaldine sulphate and muscle relaxant diazepam on Sea Bream juveniles (Sparus aurata). Israeli Journal of Aquaculture 51:143-147.

Lorenzo, D., D. Paz, E. Dellacassa, P. Davies, R. Vila, and S. Cañigueral. 2002. Essential oils of Mentha pulegium and Mentha rotundifolia from Uruguay. Brazilian Archives of Biology and Technology 45:519-524.

Marking, L. L., and F. P. Meyer. 1985. Are better anesthetics needed in fisheries? Fisheries 10(6):2-5.

Matos, F. J. A. 2000. Plantas medicinais: guia de seleção e emprego de plantas usadas em fitoterapia no Nordeste do Brasil, 2nd edition. Imprensa Universitária-Universidade Federal do Ceará, Fortaleza, Brazil.

Mazzafera, P. 2003. Efeito alelopático do extrato alcoólico do cravo-da-í ndia e eugenol. Revista Brasileira de Botânica 26:231-238.

Mello, R. A., L. S. Costa, D. Okamura, F. G. Araujo, P. A. P. Ribeiro, F. M. Correa, and P. V. Rosa. 2012. Avaliação de 2-fenoxietanol e mentol como agentes anestésicos em tilápias. Boletim do Instituto de Pesca, São Paulo Brasil 38:53-59.

Millan-Ocampo, L., A. Torres-Cortés, G. A. Marín-Méndez, W. Ramírez-Duart, M. A. Vásquez-Piñeros, and I. S. Rondón-Barragán. 2012. Anesthetic concentration of eugenol in Angelfish (Pterophyllum scalare). Revista de Investigaciones Veterinarias del Perú 23:171-181.

Mitjana, O., C. Bonastre, D. Insua, M. V. Falceto, J. Esteban, A. Josa, and E. Espinosa. 2014. The efficacy and effect of repeated exposure to 2-phenoxyethanol, clove oil and tricaine methanesulphonate as anesthetics agents on juvenile Angelfish (Pterophyllum scalare). Aquaculture 433:491-495.

Myszkowski, L., R. Kamiński, and J. Wolnicki. 2003. Response of juvenile Tench Tinca tinca (L.) to the anaesthetic 2-phenoxyethanol. Journal of Applied Ichthyology 19:142-145.
Okamura, D., F. G. Araújo, P. V. Rosa, R. T. F. Freitas, L. D. S. Murgas, and M. P. Cesar. 2010. Influência da concentração de benzocaína e do comprimento dos peixes na anestesia e na recuperação de Tilápias-do-Nilo. Revista Brasileira de Zootecnia 39:971-976.

Patel, T., Y. Ishiuji, and G. Yosipovitch. 2007. Menthol: a refreshing look at this ancient compound. American Academy of Dermatology 57:873-878

Pérez, E., F. Díaz, and S. Espina. 2003. Thermoregulatory behavior and critical thermal limits of Angelfish Pterophyllum scalare (Lichtenstein) (Pisces: Cichlidae). Journal of Thermal Biology 28:531-537.

Ramos, F. M., N. C. Sousa, M. V. S. Couto, R. G. A. Reis, N. O. Cruz, L. B. Recuero, P. C. F. Carneiro, and R. Y. Fujimoto. 2015. Uso de eugenol como anestésico para três espécies de acaris ornamentais amazônicos. Pages 1161-1166 in XIX Congresso Brasileiro de Engenharia de Pesca. São Luiz, Maranhão, Brazil.

Ribeiro, F. D. A. S., B. D. L. Preto, and J. B. K. Fernandes. 2008. Sistemas de criação para o acará-bandeira (Pterophyllum scalare). Acta Scientiarum Animal Science, Maringá 30:459-466.

Ross, L. G. 2001. Restraint, anaesthesia, and euthanasia. Pages 75-83 in W. H. Wildgoose, editor. BSAVA manual of ornamental fish, 2nd edition. British Small Animal Veterinary Association, Gloucester, UK.

Ross, L. G., and B. Ross. 1999. Anaesthetic and sedative techniques for aquatic animals, 2nd edition. Blackwell Science, Oxford.

Roubach, R., L. C. Gomes, and A. Val. 2001. Safest level of tricaine methanesulfonate (MS-222) to induce anesthesia in juveniles of Matrinxã Brycon cephalus. Acta Amazonica 31:159-163.

Roubach, R., and L. V. Gomes. 2001. O uso de anestésico durante o manejo de peixes. Panorama da Aquicultura 11:37-40.

Roubach, R., L. C. Gomes, F. A. L. Fonseca, and A. L. Val. 2005. Eugenol as an efficacious anaesthetic for Tambaqui, Colossoma macropomum (Cuvier). Aquaculture Research 36:1056-1061.

SAS Institute. 2014. SAS/STAT version 13.2 user's guide. SAS Institute, Cary, North Carolina.

Soriano, M. B. S., and D. H. Ocampo. 2002. Tasa de crecimiento del pez ángel Pterophyllum scalare (Perciformes: Cichlidae) en condiciones de laboratorio. Acta Universitaria 12:28-33.

Souza, R. A. R., C. V. A. Carvalho, F. F. Nunes, B. R. Scopel, J. D. Guarizi, and M. Y. Tsuzuki. 2012. Efeito comparativo da benzocaína, mentol e eugenol como anestésicos para juvenis de robalo peva. Boletim do Instituto de Pesca, São Paulo 38:247-255.

Tarkhani, R., A. Imani, H. Jamali, and H. G. Farsani. 2017. Anaesthetic efficacy of eugenol on various size classes of Angelfish (Pterophyllum scalare Schultze, 1823). Aquaculture Research 48:4263-5270.

Teixeira, E. G., A. G. L. Moreira, L. Moreira, and F. R. D. S. Lima. 2011. Mentol como anestésico para diferentes classes de tamanho de Tilápia do Nilo. Archives of Veterinary Science 16:75-83.

Thomas, P., and L. Robertson. 1991. Plasma cortisol and glucose stress responses of Red Drum (Sciaenops ocellatus) to handling and shallow water stressors and anesthesia with MS-222, quinaldine sulfate, and metomidate. Aquaculture 96:69-86.

Vidal, L. V. O., R. C. B. Albinati, A. C. L. Albinati, A. D. Lira, T. R. Almeida, and G. B. Santos. 2008. Eugenol como anestésico para a Tilápia-do-Nilo. Pesquisa Agropecuária Brasileira 43:1069-1074.

Woody, C. A., J. Nelson, and K. Ramstad. 2002. Clove oil as an anesthetic for adult Sockeye Salmon: field trials. Journal of Fish Biology 60:340-347. 